\title{
CAREER DECISION-MAKING ATTRIBUTION AND SELF EFFICACY: THE MODERATING ROLE OF EMOTIONAL INTELLIGENCE
}

\author{
Rose Mini Agoes Salim, Shahnaz Safitri \\ Faculty of Psychology, Universitas Indonesia \\ UI Campus, Depok, Jawa Barat, Indonesia - 16424 \\ romy.prianto@gmail.com
}

\begin{abstract}
It is known that gifted high-school students tend to have difficulty in choosing career due to their wide-range interests and capabilities. In order to successfully making an appropriate career choice, having a high level of career decision making self-efficacy (CDMSE) is an important precondition. CDMSE is the belief in one's ability to successfully complete the task necessary to make career-related decisions. Of several factors known to be affecting CDMSE, previous study has shown that career decision-making attribution (CDMA) could affect students CDMSE. However, the CDMA effect on CDMSE in gifted student is seemed to be related to personal trait of students, namely emotional intelligence (EI). Therefore, this study aims to examine the moderating role of EI on the impact of gifted high-school student CDMA on CDMSE. Subjects in this study were gifted high school students $(\mathrm{N}=165 ; 52.12 \%$ males; $\mathrm{M}$-age $=16.20$ years old $)$ in Jakarta. The measurement tools used are CDMSE Scale Short-Form, Assessment of Attribution for Career Decision Making, and Trait Emotional Intelligence Questionnaire Short-Form (TEIQue-SF) adapted into Indonesian language. The data were analyzed using simple regression analysis with Hayes PROCESS model. It was found that there is a direct effect of CDMA on CDMSE with $(F(1,163)=10.6661, p=.0033<.001)$, in which CDMA serves as a predictor of CDMSE. We also found that EI can serve as a predictor of $\operatorname{CDMSE}(F(1,163)=10.6661, p=.0007<.001$. However, EI did not moderate the CDMA-CDMSE relation. Discussion, limitations, and suggestions for further research are listed.
\end{abstract}

Keywords: career decision-making attribution; career decision making self-efficacy; emotional intelligence

\begin{abstract}
Abstrak
Siswa berbakat di jenjang sekolah menengah atas (SMA) cenderung mengalami kesulitan dalam memilih karier karena beragamnya minat dan kemampuan yang dimiliki. Agar dapat berhasil membuat pilihan karier yang tepat, adanya efikasi diri yang tinggi untuk membuat keputusan karier (CDMSE) menjadi penting. CDMSE adalah keyakinan diri seseorang untuk berhasil menuntaskan tugas yang diperlukan terkait pembuatan keputusan karier. Dari beberapa faktor yang mempengaruhi CDMSE, penelitian sebelumnya menunjukkan bahwa atribusi atas pengambilan keputusan karier (CDMA) dapat mempengaruhi CDMSE siswa. Namun, efek CDMA pada CDMSE, khususnya pada siswa berbakat berkelindan dengan karakteristik pribadi siswa berupa kecerdasan emosi. Oleh sebab itu, penelitian ini bertujuan untuk menguji efek moderasi dari kecerdasan emosi dalam hubungan antara CDMA dan CDMSE pada siswa SMA berbakat. Penelitian dilakukan pada siswa SMA berbakat $(\mathrm{N}=165 ; 52.12 \%$ laki-laki; M-usia $=16.20$ tahun $)$ di Jakarta dengan alat ukur berupa skala CDMSE short-form, skala Assessment of Attribution for Career Decision Making, dan skala Trait Emotional Intelligence Questionnaire Short-Form (TEIQue-SF) yang diadaptasi ke Bahasa Indonesia. Analisis data dengan teknik sederhana regresi menggunakan model PROSES Hayes menunjukkan bahwa terdapat efek langsung CDMA terhadap CDMSE $(F(1,163)=10,6661, p=0,0033<0,001)$, di mana CDMA berfungsi sebagai prediktor dari CDMSE. Kecerdasan emosi juga berfungsi sebagai prediktor CDMSE $(F(1,163)=10,6661, p=0,0007$, $<0,001$ tetapi tidak memoderasi hubungan antara CDMA dan CDMSE. Diskusi, limitasi, dan saran penelitian terlampir.
\end{abstract}

Kata kunci: career decision-making attribution; career decision making self-efficacy; emotional intelligence

INTRODUCTION

Adolescence is an important period for individual to start building their future career.
It is known as one of several major developmental tasks to be met by individual before they are grown into an adult (Santrock, 2014). In building a career, the 
first mandatory step is to choose which career individual will pursue to further start making plan to achieve that particular career. In this process, there are various things to be considered and decided, such as whether to enter immediately into the workforce or to continue education first and also what type of workforce or academic major to be enrolled (Fabio \& Kenny, 2011; Sersiana, Lukitaningsih, Muis, \& Purwoko, 2013).

It is known that the process of choosing and planning a future career often involves unexpected changes along the way (Fabio \& Kenny, 2011). This uncertainty often leads the adolescent to experience anxiety and stress, which making them explore their future career with hesitation and do not seriously doing so (Fabio, Palazzeschi, Asulin-Peretz, \& Gati, 2013; Santrock, 2014). Cheung, Cheung, and $\mathrm{Wu}$ (2014) stated that the anxiety felt by these adolescents is a result of a lack capability on career selection. Not only result in career indecision during career building period, this anxiety also produces further problems over time by making the youths later regret their own career decision (Sawitri, 2009).

In Indonesia, career indecision is prevalent among high school students (Sawitri, D. R., Creed, P. A., and Zimmer-Gembeck, 2015; Sawitri, 2009). According to the survey conducted by Indonesian Central Bureau of Statistics in 2018, it was found that the high school graduates, both in regular school and vocational school, are those with the highest percentage of unemployment compared to the other educational background. They amounts to $16.11 \%$ from the total of 6.8 million unemployed youths in Indonesia (Kusuma, 2018). Here, students are taught in an education system where they need to choose between high school or vocational school and its corresponding majors as early as $10^{\text {th }}$ grade in their transition from junior to senior high school. However, the students are often recklessly choosing their field of study, which further lead to another indecision in choosing a career after graduate with a high school diploma (Sersiana et al., 2013).

Nevertheless, career indecision is also a common problem faced by many adolescents around the globe. Responding to this issue, numerous studies had been conducted to seek factors related to career indecision. Study by Bolat and Odac1 (2017), Choi et al. (2012), also by Sawitri (2009) in addressing Indonesian context, found that Career Decision Making Self-Efficacy (CDMSE) plays a key role in career planning and development in adolescents. CDMSE is belief that individual can successfully complete the necessary tasks to make careerrelated decisions (Betz, Klein, \& Taylor, 1996). Another definition emphasizes CDMSE in terms of perceived capability, which defines it as individual's confidence in his or her ability to perform certain tasks related to career decision making (Buyukgoze-Kavas, 2014). CDMSE is built on the basis of Bandura's concept of selfefficacy, combined with theory of career maturity in vocational psychology. Thus, it is further stated that CMDSE are the major mediator of behavior and behavior change, especially in the career related building (Buyukgoze-Kavas, 2014; Miguel, Silva, \& Prieto, 2013).

Since CDMSE involves a positive belief in one's capacity, it is therefore found that high CDMSE enhance the likelihood of students to engage in career exploration directly or indirectly by having intention to engage in the process (Miguel et al., 2013). In the long run, CDMSE positively effects career development by making it easier to students in deciding their career and then committed to their choice (Bullock-Yowell, Andrews, \& Buzzetta, 2011). Another study by Jiang (2014) supported the notion of how CDMSE impacts the ease of career choosing. In his study, it is found that individuals who are confident in making career choices are less confused in doing so. Taken from another perspective, study by Fabio et al. (2013) found that indecision about careers often 
occurs due to low levels of confidence in ability. Therefore, a high CDMSE level indicates that an individual has a positive career attitude (Choi et al., 2012).

CDMSE belief, as one form of self-efficacy, is built through many ways. One of the powerful sources of developing it is from mastery experience, where a cumulative past experience of success or failure shape individual's belief of his/her capacity in performing the corresponding task. It is said that this belief of capacity is formed by the interpretation the individual holds when facing his/her success or failure. When they think their success comes from their effort, then their confidence in performing on related task increases, and vice versa (Watters, 2010). In terms of career, having a successful experience related to career activity develops an individual's confidence to achieve the desired career, thus build the person's CDMSE.

The process of interpreting the cause of one's performance outcome is known as attribution. In the context of career outcome, the term used are career decision-making attribution (CDMA), defined as one's belief about the cause of success or failure experiences in career development (Luzzo \& Jenkins-Smith, 1998). According to CDMA, people can produce various beliefs regarding the reason behind their experience in career, which is evaluated around three dimensions. The dimension of causality explains whether the perceived reason is internal (personattribute) or external (environmentalattribute). The control dimension refers to how much control an individual has on the attained outcome and his or her sense of responsibility for it. The stability dimension refers to whether the perceived reason is stable in nature or unstable which can change depending on the background context (Schunk, Pintrich, \& Meece, 2010).

Taken from all CDMA dimensions, there are two attribution styles namely optimistic versus pessimistic career decision-making attribution. The optimistic style is the belief that career decision outcome is caused by internal or person's act, controllable by the person, and changeable according to the context. In contrast, pessimistic style is the belief that career decisions outcome are caused by external or environmentally explained, uncontrollable by person, and stable across time and space. Research has shown that the more optimistic the career decision-making attribution style, the more assured the students were in their career decision-making ability (Luzzo \& JenkinsSmith, 1998).

Despite CDMA being a major factor on CDMSE, the effect of attribution to CDMSE can also occur through the experience of emotional state that arise along the way. Each dimension of CDMA is said to produce different set of emotional responses. For example, dimension of internal causality is related to the person's sense of pride, which then correlates to CDMSE (Choi et al., 2012). In addition, dimension of stability raises a sense of hopefulness or helplessness within individual in facing environmental situation (Schunk et al., 2010). Furthermore, it is known that in general the process of career choosing and planning is composed of any possible unexpected events, which turns out induce various emotions in individual (Fabio \& Kenny, 2011; Murtagh, Lopes, \& Lyons, 2011). Since individual will not always experience only positive outcome in their life, this fact implies that the ability to modulate emotion to regulate action in terms of career orientation and development are necessary. This ability is known as emotional intelligence (Fabio \& Kenny, 2011; Joseph \& Newman, 2010; Mayer, Caruso, \& Salovey, 2016).

Emotional intelligence is a cognitiveaffective characteristic which support individual development across academic, social, and career domains. This is due to the emotional intelligence's role in enabling individual to effectively process and integrate emotion with reason. In the case of career 
choosing, this characteristic protects us from becoming emotionally overwhelmed thus facilitate decision making (Fabio \& Kenny, 2011). Individuals with high emotional intelligence have such an awareness of their current emotional states, which make them better at integrating emotional experiences with their thoughts and actions to attain a goal (Afzal, Atta, \& Shujja, 2013). This capacity then supports the individual to stay confident in the process and succession of executing career choosing and planningrelated tasks. Moreover, it was found that intervention aimed at enforcing emotional intelligence in adolescent is beneficial to support their career progress (Fabio \& Kenny, 2011). A followed-up research by Fabio, Palazzeschi, Asulin-Peretz, \& Gati (2013) later found that emotional intelligence as the ability to correctly perceive emotional states explained the $10 \%$ of the total variation on the individual confidence level for making career decisions. Furthermore, emotional intelligence facilitates career decisionmaking self-efficacy, where emotion that is in control and stable allows individual in doing self-appraisal, obtaining information on career, prioritizing goals and planning for career, and solving problems in deciding career (Mayer et al., 2016); all of the aspects of career decision making self-efficacy itself.

Especially for adolescent, high emotional intelligence makes them more likely to feel satisfied with their social support systems in order to advance their surroundings according to their targeted goal. In respect to career, they are also found to be motivated to determine and actualize the plans and programs they have chosen and created (Schutte \& Loi, 2014). Therefore, it is concluded that emotional intelligence can play as a promising predictor for career decision-making self-efficacy too. In respect to the role CDMA plays directly on CDMSE while also inducing certain positive and negative emotions within individual, it makes the trait of emotional intelligence is beneficial to have in supporting the attainment of personal goal. At the same time, emotional intelligence also has a positive role on supporting the level of CDMSE. Taken together, it might seems that emotional intelligence can serve as a moderator in the relationship between CDMA and CDMSE by strengthening this established relationship.

Among many adolescents, there are some of them who possess the trait of giftedness. Based on the theory of Three Ring Conception by (Renzulli, 1978), gifted adolescents are those who have a combination of above-average intelligence and creativity, and a high level of task commitment. In the career building process, gifted students are reported to be full of excitement on their future attainment, involve deeply on their chosen field of works, all of which bolster them to achieve a state of career maturity earlier than their peers (Watters, 2010). In addition, gifted adolescents are believed to be able on achieving a high-quality performance in various fields of life (Davis, Rimm, \& Siegle, 2011), especially since they are also known to have a wide range of interests and talents (Watters, 2010). In contrast, another research highlights that gifted students can also experience anxiety in choosing career because they have so many possibilities and options which lead to confusion (Jung, 2018). It is stated that their higher capacity on cognitive functioning has a drawback of a higher sensitivity to process emotional input, which makes gifted students easily feel hurt, guilty, depression, inadequate, and fear (Davis et al., 2011). Taken together, it is known that gifted adolescents are challenged by their emotional states while on another case they are also likely to be capable of combining emotions and intellect to adapt in their environment (Woitaszewski \& Aalsma, 2004).

Along with the dual characteristics of emotionality on gifted adolescents, Watters (2010) in his research advised for taking into account the emotional factors of gifted students in respect to their career building to 
avoid indecision, anxiety, and fear of failure. It is said that the unique ability of gifted students flourishes if emotions, intellect, and creativity are integrated together to achieve their goals (Mayer et al., 2016; Mayer, Perkins, Caruso, \& Salovey, 2001). Therefore, this study aims to seek if emotional intelligence serves as a moderator in the relationship between CDMA and CDMSE in gifted adolescents, especially gifted high school students. This is done due to the fact that in Indonesia, students are mandated to make a concrete career decision as they enroll to senior high school. To date, little is known on gifted students' CDMSE levels (Watters, 2010) compared to other type of self-efficacy. The same also applies to their perceived attribution on their attained outcome in the context of career decisionmaking process.

Thus, our study aims to investigate whether: 1) CDMA serves as a significant predictor of CDMSE in gifted high school students. Based on the background explained above, we hypothesized that CDMA will significantly predicts CDMSE in gifted high school students; 2) Emotional intelligence serves as a significant predictor of CDMSE in gifted high school students. The past researches on this topic suggest that emotional intelligence will significantly predicts CDMSE in gifted high school students; 3) Emotional intelligence moderates the relationship between CDMA and CDMSE in gifted high school students. The past researches done on this topics lead us to hypothesize that emotional intelligence will strengthens the relationship between CDMA and CDMSE in gifted high school students.

\section{METHOD}

\section{Research Design}

This study used a non-experimental quantitative approach to examine the relationship between career decision making self-efficacy (CDMSE), career decision- making attribution (CDMA), and emotional intelligence.

\section{Participants and Sampling Procedure}

Data collection consisted of a cross-sectional approach based on purposive sampling. The study was carried out in a face to face interaction between the researchers and the participants. We first contacted several leading public high schools' principal to get an official approval to conduct the study. After the study is permitted with a school's reference date for data collection, we then came to each classes and delivered psychological assessments first in a classical group testing. In doing so, we hired 16 school psychologists to deliver the psychological assessments. These assessments are given as a way to further filtering and identifying gifted students. After that, the assessments were followed by the administration of research questionnaires.

We then filtered out the all the students who are willing to participate in the study to seek only the gifted students. Following the guidance on the Three Ring Conception of Giftedness by Renzulli (1978), we identify the gifted students by measuring their intelligence, creativity, and task commitment. Based on this theory, gifted students are those scored (a) above average on intelligence (scored $\geq 120$ as obtained from the Intelligence Structure Test/IST), above average on creativity (scored $\geq 110$ on Tes Kreativitas Figural Indonesia), and high on task commitment (scored $\geq 132$ on Task Commitment Scale); or those with (b) a superior intelligence (scored $\geq 130$ on IST). After the assessment was analyzed, there were 165 gifted high school students found. Their age are ranging from 15 to 17 years $(\mathrm{M}$ $=16.20 ; \mathrm{SD}=.652$ ), which consist of $\mathrm{N}=77$ $(48.13 \%)$ male students and $\mathrm{N}=88(51.87 \%)$ female students.

\section{Measurements}

Before collecting the data, we started by adapting the scale used into Indonesian language and matching the scale items in 
terms of context, with the help of one school psychologist and one clinical psychologist. We also tried out the scale by administering it to several high school students to test its readability and to ensure the participants understanding of the items included.

\section{Career Decision Self-Efficacy Scale-Short Form (CDMSE-SF)}

To measure participants' level of career decision making self-efficacy, we use Career Decision-Making Self-Efficacy Scale (CDMSE-SF) in the short version as revised by Betz et al. (1996). It is known that CDMSE-SF is the most widely used measure of career decision making self-efficacy globally, with no issue on its validity (Gaudron, 2011; Török, Tóth-Király, Beáta, \& Orosz, 2016). The scale has 25 items, with 5 items allocated to each of the 5 subscales, namely self-appraisal, occupational information, goal selection, planning, and problem solving. The available responses are on a five-point Likert scale ranging from "no confidence at all" (1) to "very confident" (6). The sample items are as follow: "I choose my own ideal career to be pursued in my future" and "I choose one of several career options that I have considered".

To ensure the construct validity of the scale, we use Confirmatory Factor Analysis (CFA) and corrected item-total correlation (crIT) procedure as validity testing. From the validity testing on a sample of $\mathrm{N}=1045$, we found that 4 items are not valid which leave 21 items in further use. The 21 items CDMSE Scale have factor loadings ranging from .42 to .75 ( $t$ value $>1.96)$ with crIT value ranging from .407 to .630 . In addition, the 21 items CDMSE Scale also yields a satisfying Cronbach's alpha $(\alpha)$ value of .901 , thus it has an excellent reliability in terms of internal consistency.

\section{Assessment of Attribution for Career Decision Making (AACDM)}

To measure career decision-making attribution style, Luzzo \& Jenkins-Smith (1998) created Assessment of Attribution for Career Decision Making (AACDM). The
AACDM has 23 items across 3 dimensions, which are controllability, stability, and causality. The available responds are 6-point Likert scale ranging from 1 ("strongly disagree") to 6 ("strongly agree") for 18 favorable items, and vice versa to another 5 unfavorable items. The rationale behind AACDM is the higher individual scored on the scale, the more optimistic attribution style the individual possess. In contrast, lower scores indicating a pessimistic attribution style. The sample items are as follow: "My career choice depends on others choices" and "My parents give a freedom in choosing my career".

After adaptation process, construct validity testing is also conducted using CFA and crIT in a sample of $\mathrm{N}=1045$, in which 11 items were found to be valid in measuring AACDM dimensions. For controllability dimension, factor loadings are ranging from $.54-.86, t$ value $>1.96$, with crIT value of .509-.567. The stability dimension yielded factor loading from .58 to $.88, t$ value $>1.96$, with crIT value of .371-.720. The causality dimension has factor loading around .55$1.14, t$ value $>1.96$, and crIT score of .509.623. In addition, the reliability of the scale is acceptable with 11 items has $\alpha$ value of .709 for controllability dimension, .805 for stability dimension, and .721 for causality dimension.

\section{Trait Emotional Intelligence Questionnaire Short Form (TEIQue-SF)}

We used Trait Emotional Intelligence Questionnaire, Short Form (TEIQue-SF) by Petrides and Furnham (in Cooper \& Petrides, 2010) to measure participants' perceptions of their emotional intelligence. The TEIQue-SF consist of 6 subscales measuring the component of trait positivity, self-control, emotionality, sociability, adaptability, and self-motivation. It includes 30 statements with 6-point Likert scale, ranging from 1 'totally disagree' to 6 'totally agree'. The sample items are as follow: "I often change my mind", "I draw myself as a good 
negotiator", and "In general, I can handle the stress well".

After adaptation, construct validity testing to a sample of $\mathrm{N}=1045$ using CFA found that 13 items as not valid in which they were eliminated. The remaining 17 items have factor loadings ranging from .410 to $.720, t$ value $>1.96$, with crIT value ranging from .338 to .596 . In addition, its reliability coefficient in terms of internal consistency is $\alpha=.852$.

\section{Data Analysis}

To test the hypothesis, we use linear regression and multiple regression analyses with Hayes's Model (Hayes, 2013). A preliminary analysis in terms of descriptive statistics and correlation analysis were performed before testing the hypothesis to reveal the distinctive statistical feature of the variables.

\section{RESULT AND DISCUSSION}

\section{Result}

\section{Preliminary Analysis}

Before hypothesis testing, some initial tests were conducted. Table 1 shows the descriptive statistics of the three research variables.

Table 1.

Descriptive Analysis of the Variables

\begin{tabular}{lcccccc}
\hline & $\begin{array}{c}\text { Possible } \\
\text { Min. Score }\end{array}$ & $\begin{array}{c}\text { Possible } \\
\text { Max. Score }\end{array}$ & $\begin{array}{c}\text { Attained } \\
\text { Min. Score }\end{array}$ & $\begin{array}{c}\text { Attained } \\
\text { Max. Score }\end{array}$ & Mean & SD \\
\hline CDMSE-SF & 21 & 126 & 55 & 124 & 96.74 & 10.56 \\
AACDM & 11 & 66 & 32 & 64 & 47.23 & 6.65 \\
TEIQue-SF & 17 & 102 & 43 & 87 & 63.83 & 9.05 \\
\hline
\end{tabular}

Note. $C D M S E=$ Career decision-making self-efficacy; AACDM = Assessment of attribution for career decision making; TEIQue-SF = Trait emotional intelligence questionnaire short form.

Based on the table above, we can see that the participants are more likely to score in the higher end of the possible scale score, as indicated by the highest total score got by the participants in contrast to the highest possible total score. In addition, the mean score of participants from all the three scales tend to be also centered on the high end. The follow up analysis showed that these scales' data distributions are all negatively skewed except for AACDM in which it has a bimodal distribution. However, the normality test using One Sample Kolmogorov-Smirnov Test indicated that the data from those three scales are still normally distributed.

As a preliminary analysis, we correlated the variables examined in the study and also some demographic attributes of participants to see if there is a relationship between them before we move to test the study hypothesis.
Table 2 shows the correlation matrix for the research variables.

Table 2.

Correlation Analysis of the Variables

\begin{tabular}{lccc}
\hline & 1 & 2 & 3 \\
\hline CDMSE-SF & 1 & & \\
AACDM & $.216^{* *}$ & 1 & \\
TEIQue-SF & $.263^{* *}$ & .022 & 1 \\
Age & .076 & .031 & .069 \\
Gender & -.092 & .034 & .113 \\
\hline
\end{tabular}

Note. $1=C D M S E=$ Career decision-making self-efficacy; $2=A A C D M=$ Assessment of attribution for career decision making; $3=$ TEIQue-SF = Trait emotional intelligence questionnaire short form. ${ }^{* *} p<.01, * p<.05$

The correlation test between the variables showed that CDMSE was significantly correlated with CDMA $(r=0.216, p=$ 0.010). CDMSE was also positively and 
significantly correlated with emotional intelligence $(r=.263, p=.001)$. However, CDMA was not correlated with emotional intelligence $(r=.022, p=.795)$. In addition, none of the three research variables was found to correlate with participants' age or gender.

\section{Hypothesis Testing}

Simple Regression Test

After calculating the means, standard deviations and correlations among all variables, the researchers performed a simple regression analysis of the CDMSE. The results of the regression analysis showed a significant influence of CDMA on CDMSE $(F(1,163)=10.666, p=0.0033,<0.005)$. The determinant coefficient $\left(R^{2}\right)$ was 0.1164 . This means that $11.64 \%$ of the variance in CDMSE can be explained by CDMA. Therefore, we conclude that Hypothesis 1 of the study is accepted. The result showed that CDMA significantly and positively predict the CDMSE in gifted high school students.

To test the Hypothesis 2, we conducted another simple linear regression test on emotional intelligence and CDMSE. We found that there is also a significant effect of emotional intelligence on CDMSE in the gifted students $(F(1,163)=10.666, \mathrm{p}=$ $0.0007,<0.001)$. The value of the determinant coefficient $\left(R^{2}\right)$ was 0.10 . This means that $10 \%$ of the variance of CDMSE can be explained through emotional intelligence. Based on the results of this test, Hypothesis 2 is accepted. This result also in line with the findings from Di Fabio et al. (2013) in which emotional intelligence accounts for the exact $10 \%$ variance person confidence level for making career decisions.

Table 3.

Output of the Moderation Effect Test

\begin{tabular}{rccccc}
\hline & & Coeff. & $S E$ & $t$ & $P$ \\
\hline Constant & & 4.61 & .036 & 125.20 & $.000^{* *}$ \\
CDMA & $b_{1}$ & .18 & .063 & 2.93 & $.003^{* *}$ \\
Emotional intelligence & $b_{2}$ & .23 & .071 & 3.25 & $.001^{* *}$ \\
Int_1 & $b_{3}$ & -.19 & .111 & -1.70 & .897 \\
\hline
\end{tabular}

Note. Dependent variable: career decision making self-efficacy

$R^{2}=.1321, M S E=.2236,{ }^{* *} p<.001$

Moderation Effect Test

Table 3 shows the summary of moderation effect test. Using macro PROCESS (Hayes, 2013), we found that there is no moderation (interaction effects) between CDMA and emotional intelligence on CDMSE $\left(b_{3}=\right.$ $-.19, t=-1.70, p=.897)$. This indicates that there is no significant influence of emotional intelligence on the relationship between CDMA and CDMSE in gifted high school students. Therefore, Hypothesis 3 is rejected in which emotional intelligence does not moderate the relationship between CDMA and CDMSE in gifted high school students.

\section{Discussion}

This study aims to investigate whether (a) CDMA and (b) emotional intelligence serves as a significant predictor of CDMSE in gifted high school students. Moreover, we also seek to investigate whether emotional intelligence moderates by strengthening the relationship between CDMA and CDMSE in gifted high school students. From the result, we found that both CDMA and emotional intelligence significantly predict the gifted high school students CDMSE. However, we found that the emotional intelligence does not moderate the relationship between CDMA and CDMSE in these students.

Taking from the perspective of social cognitive career theory, it is said that the personality trait is the main factors in shaping the CDMSE (Hsieh \& Huang, 2014). Previous research had tried to depict the role of personality trait on CDMSE by measuring 
its relation with personality construct, such as Five Factor Model Trait. This research actually follows that stream of research, but instead of portraying personality trait in a continuum, we choose the special population of gifted adolescent to shed lights on the dynamic of CDMSE as they perceived. In the case of gifted high school students, there might be a different case that going on. Due to their higher level of personal capacity in terms of intelligence, creativity, and task commitment which exceeding their average peers, gifted high school students often already possess an optimistic belief of their capacity to build their own future. They generally found to believe that the success they experienced in school is caused by their internal attribute or capacity (Valdés-Cuervo, Sánchez Escobedo, \& Valadez-Sierra, 2015), thus the same attribute they have could later help them in achieving their desired career. It is not surprising that in this study, all the participants scored moderate to high on AACDM which measure how optimistic they are on their capacity to achieve desired career $(\mathrm{M}=47.23$, high level of CDMA). Therefore, it is acceptable that CDMA could positively predict the level of CDMSE the gifted students have.

In respect to the role of emotional intelligence has on CDMSE, previous study on CDMSE by Fabio et al. (2013) indicated that high school adolescents typically use their emotional states as guidance for their thinking process when exploring new experience related to the career aspiration. Furthermore, emotion was also highlighted for its function in facilitating the process of making an accurate self-appraisal for one's current capacity related to career, gathering any relevant information, and also formulating a goal in career building. All these processes are known to be fruitful as they turned out to become a concrete action of career planning, and also concrete solution when solving the possible problem faced along the way. Another research by Mayer et al. (2016) summarized that emotions indeed involve in facilitating thoughts. The way it is facilitating the thought could be found in many ways, be it in appraising the situation, analyzing the problem found in respect to the person's goal, judging the best achievable solutions, and remembering the relevant things related to one's goal. All these refer to emotion as a supporting agent for the cognitive process to excellently do its function.

In this study, the finding that emotional intelligence predicts the CDMSE is in line with the previous research. All previous studies show that emotional intelligence plays a role in terms of integrating the perceived emotion and desired goal, which further motivating the person to feel capable of CDMSE (Fabio \& Kenny, 2011; Fabio et al., 2013; Joseph \& Newman, 2010). Nevertheless, as we consider the experience of gifted students, thus their salient characteristic needs to be considered. Gifted students are famous for their high level of motivation for accomplishing a given tasks, which are known as task commitment. In this study, we use the measurement of emotional intelligence of TEIQue-SF which includes the self-motivation as one components of the emotional intelligence measured (Cooper \& Petrides, 2010). Thus, it is not surprising that gifted students in this study got a high score on emotional intelligence measurement, since they are definitely the groups of people characterized by high in motivation, which further also predicts their CDMSE level.

Taken together, a bigger picture emerges on the relationship among these variables. It is noted that an internal motivation, portrayed as self-motivation in TEIQue-SF, foster the gifted students to persist on their tasks and show effort during the task completion. This is the very reason on gifted student likelihood to adapt and hold an optimistic attribution style. Gifted students internal motivation makes them to show effort in doing task and shape them not to holding a static view of ability, in other word they tend to have an optimistic belief that they can do whatever they put their mind into (Watters, 2010). 
However, it could also emerge that a pessimistic belief of ability becomes the main booster for them to show efforts during the task completion related to career. While internal motivation has already become their defining characteristic of giftedness, a pessimistic view of their ability will also elicit a strong willingness to work hard on achieving their desired goals instead of becoming avoidant and indecisive. It is known that career planning are generally determined by the interaction of internal psychological factors and external sociocultural within the environment (Watters, 2010). In the case of gifted students, they are prone to be sensitive by easily feeling hurt, guilty, and inadequate, especially if they are placed on the highability grouping together with the other high achievers to be their relative for social comparison. This sensitivity links to the pessimistic belief of ability, yet it can function as a main driver behind the gifted students' eagerness to work hard in attaining their goals of career. Due to the objectively high ability as they posses, the feeling of lacking can be compensated with more effort in achieving goals (Davis et al., 2011; Watters, 2010). This possibility is indicated by the distribution of attribution style as measured by AACMD, in which there is a bimodal distribution with one below and one above the mean score, while the overall mean score is still on the high end of the scale. Thus, even though both CDMA and emotional intelligence predicts CDMSE, we found that there is no correlation between CDMA and emotional intelligence $(r=.022$, $p=.795)$.

In respect to the dual attribution style might be possess by gifted high school students, there are some consequences. Unlike the typical high school students whom the emotional intelligence serves mainly as a supporting aspect of CDMA to influence CDMSE, the gifted high school students seem to be influenced by it only as a main factor of CDMSE. This is due to the emotional intelligence as a defining trait of giftedness in terms of motivation. Thus, apart from the attribution style they might possess, the emotional intelligence already plays role to make gifted students stick to their career decision making process. Hence, we found that the emotional intelligence could not moderate the relationship between the CDMA and CDMSE and need to be considered by viewing it as a main predictor of the CDMSE. In addition, we are acknowledging that there are the gifted students who lack of self-motivation and often mentioned as underachiever. However, in this study this is not the case since our participants are all gathered from a leading senior high school in Indonesia capital city, and then further filtered through a psychological assessment conducted by school psychologist.

Our findings will have some implications on the way school delivers a career coaching and counseling to its students. Watters (2010) have warned that the considerable attention should be given to the gifted students as the future generation capable to innovate and become creative and productive thinkers. Along with this advice, this study brings attention to the need of school board in identifying its students' characteristics related to the career planning process, where in this study we only brought up the characteristic of giftedness to be taken into account. The second implication refers to the emphasis on building the students' CDMSE first before move forward to make students have a clear and visionary career plan. In order to do so, this study gives some highlight that school can start by shaping its students to have an optimistic belief of their capability, and also try to shape their emotional intelligence to successfully deal with negative emotions and sticking themselves to their desired goals. Both of these traits mentioned are not an instant to be built within the students' personality, but more of a gradual improvement as students learning in school from day to day. In general, school preparation for assisting its students' career choosing and planning 
actually take place as soon as students stepping their foot on the school, not just on their final year before graduation.

Nevertheless, this study has several limitations. The first is the nature of nonexperimental design as applied in this study. Using this design, there seems to be quite lack of control on extraneous variable which may interfere the relationship among variables under investigation. Although we have tried to do statistical control for demographic variable namely age and gender, another kind of control is advisable. Furthermore, an experimental study design can be applied in which the gifted participant is randomized into a different group as a standard on controlling extraneous variable. Another limitation is the scope of the study where the gifted children investigated are all coming from a leading school in an urban city. The different result of study could be the case if the gifted child is someone living in rural area or studying in an ordinary school.

\section{CONCLUSION}

The result of this study shows us that CMDSE could be predicted from the gifted students' level of CDMA and emotional intelligence. However, emotional intelligence does not serve as a moderator on the relationship between CDMSE and CDMA. This finding implies that emotional intelligence should be taken into account as a direct predictor which has direct contribution to the level of CDMSE, even though it has a lesser value of coefficient determinant $\left(\mathrm{R}^{2}\right)$ than CDMA has on CDMSE.

\section{ACKNOWLEDGEMENT}

This research will not be successfully conducted without the support of PITTA Grant from Universitas Indonesia as the main sponsor for funding. We also would like to thank Melly Preston, Azkya Milfa Laensadi, Dhaniar Gusna Fatimah, and Rosliyanti for helping us in the data entry process.

\section{REFERENCES}

Afzal, A., Atta, M., \& Shujja, S. (2013). Emotional intelligence as predictor of career decision making among university undergraduates. Journal of Behavioural Sciences, 23(1), 118131.

Betz, N. E., Klein, K. L., \& Taylor, K. M. (1996). Evaluation of a short form of the career decision-making selfefficacy scale. Journal of Career Assessment, 4(1), 47-57. doi:10.1177/10690727960040 0103

Bolat, N., \& Odac1, H. (2017). High School Final Year Students' Career Decision-Making Self-Efficacy, Attachment Styles and Gender Role Orientations. Current Psychology, 36(2), 252-259. doi:10.1007/s12144016-9409-3

Bullock-Yowell, E., Andrews, L., \& Buzzetta, M. E. (2011). Explaining career decision-making self-efficacy: Personality, cognitions, and cultural mistrust. Career Development Quarterly, 59(5), 400-411. doi:10.1002/j.21610045.2011.tb00967.x

Buyukgoze-Kavas, A. (2014). A psychometric evaluation of the Career Decision Self-Efficacy Scale - Short Form with Turkish university students. Journal of Career Assessment, 22(2), 386-397. doi: $10.1177 / 1069072713484561$

Cheung, C. K., Cheung, H. Y., \& Wu, J. (2014). Career unreadiness in relation to anxiety and authoritarian parenting among undergraduates. International Journal of Adolescence and Youth, 19(3), 336-349. doi:10.1080/02673843.2014.928784

Choi, B. Y., Park, H., Yang, E., Lee, S. K., 
Lee, Y., \& Lee, S. M. (2012). Understanding Career Decision SelfEfficacy: A Meta-Analytic Approach. Journal of Career Development, 39(5), $\quad 443-460$. doi:10.1177/08948453113980 42

Cooper, A., \& Petrides, K. V. (2010). A psychometric analysis of the Trait Emotional Intelligence Questionnaire-Short Form (TEIQueSF) using item response theory. Journal of Personality Assessment, 92(5), 449-457. doi:10.1080/00223891. 2010.497426

Davis, G. A., Rimm, S. B., \& Siegle, D. (2011). Education of The Gifted and Talented. New Jersey, NJ: Pearson Education, Inc.

Fabio, A. Di, \& Kenny, M. E. (2011). Promoting emotional intelligence and career decision making among Italian high school students. Journal of Career Assessment, 19(1), 21-34. doi:10.1177/ 1069072710382530

Fabio, A. D., Palazzeschi, L., Asulin-Peretz, L., \& Gati, I. (2013). Career indecision versus indecisiveness: Associations with personality traits and emotional intelligence. Journal of Career Assessment, 21(1), 42-56. doi:10.1177/ 1069072712454 698

Gaudron, J. (2011). A psychometric evaluation of the Career Decision Self-Efficacy Scale - Short Form among French university students. Journal of Career Assessment, 19(4), 420-430. doi:10.1177/1069072711 409713

Hayes, A. . (2013). Introduction to Mediation, Moderation, and Conditional Process Analysis: A Regression-Based Approach. New York, NY: The Guilford Press.
Hsieh, H. H., \& Huang, J. T. (2014). The effects of socioeconomic status and proactive personality on career decision self-efficacy. Career Development Quarterly, 62(1), 29$43 . \quad$ doi: $10.1002 / \mathrm{j}$ 21610045.2014.00068.x

Jiang, Z. (2014). Emotional intelligence and career decision-making self-efficacy: National and gender differences. Journal of Employment Counseling, 51(3), 112-124. doi:10.1002/j.21611920.2014. 00046.x

Joseph, D. L., \& Newman, D. A. (2010). Emotional Intelligence: An Integrative Meta-Analysis and Cascading Model. Journal of Applied Psychology, 95(1), 54-78. doi:10.1037/a0017286

Jung, J. Y. (2018). Occupational/career amotivation and indecision for gifted and talented adolescents: A cognitive decision-making process perspective. Journal of Psychologists and Counsellors in Schools, 28(2), 185196. doi:10.1017/jgc.2016.33

Kusuma, H. (2018, May 7). Pengangguran RI 6,87 Juta Orang, Paling Banyak Lulusan SMK. Retrieved from: https://finance.detik. com/beritaekonomi-bisnis/d-4009017/peng angguran-ri-687-juta-orang-palingbanyak-lulusan-smk

Luzzo, D. A., \& Jenkins-Smith, A. (1998). Development and initial validation of the assessment of attributions for career decision-making. Journal of Vocational Behavior, 52(2), 224-245. doi:10.1006/jvbe.1997.1582

Mayer, J. D., Caruso, D. R., \& Salovey, P. (2016). The ability model of emotional intelligence: Principles and 
updates. Emotion Review, 8(4), 290300. doi:10.1177/1754073916639667

Mayer, J. D., Perkins, D. M., Caruso, D. R., \& Salovey, P. (2001). Emotional intelligence and giftedness. Roeper Review, 23(3), 131-137. doi:10.1080/ 02783190109554084

Miguel, J. P., Silva, J. T., \& Prieto, G. (2013). Career Decision Self-Efficacy Scale - Short Form: A Rasch analysis of the Portuguese version. Journal of Vocational Behavior, 82(2), 116-123. doi:10.1016/j. jvb.2012.12.001

Murtagh, N., Lopes, P. N., \& Lyons, E. (2011). Decision making in voluntary career change: An other-than-rational perspective. Career Development Quarterly, 59(3), 249-263. doi:10.1002/j.2161-0045.2011. tb00067.x

Renzulli, J. S. (1978). What makes giftedness? Reexamining a definition. Phi Delta Kappan, 60(3), 180-184. Retrieved from: https://eric.ed.gov/?id=EJ190430

Santrock, J. W. (2014). Adolescence. New York, NY: McGraw-Hill.

Sawitri, D. R., Creed, P. A., and Zimmer-Gembeck, M. J. (2015). Longitudinal relations of parental influences and adolescent career aspirations and actions in a collectivist society. Journal of Research on Adolescence, 25(3), 551-563. doi:10.1111/jora.12145

Sawitri, D. . (2009). Pengaruh status identitas dan efikasi diri keputusan karier terhadap keraguan mengambil keputusan karier pada mahasiswa tahun pertama di Universitas Diponegoro. Jurnal Psikologi Undip, 5(2), 1-14.
Schunk, D. H., Pintrich, P. R., \& Meece, J. L. (2010). Motivation in Education: Theory, Research, and Application. New Jersey, NJ: Pearson Education.

Schutte, N. S., \& Loi, N. M. (2014). Connections between emotional intelligence and workplace flourishing. Personality and Individual Differences, 66, 134-139. doi:10.1016/j.paid.2014. 03.031

Sersiana, L., Lukitaningsih, R., Muis, T., \& Purwoko, B. (2013). Hubungan antara self-efficacy karier dan persepsi terhadap masa depan karier dengan kematangan karier siswa SMK PGRI Wonoasri tahun ajaran 2012/2013. Jurnal BK UNESA, 3(1), 172-180.

Taylor, K. M., \& Betz, N. E. (1983) Applications of self-efficacy theory to the understanding and treatment of career indecision. Journal of Vocational Behavior, 22(1), 63-81. doi:10.1016/ 0001-8791 (83)90006-4

Török, R., Tóth-Király, I., Beáta, B., \& Orosz, G. (2016). Analyzing models of career decision self-efficacy : Firstorder, hierarchical, and bifactor models of the Career Decision SelfEfficacy Scale. Current Psychology, 36(4), 764-773. doi:10.1007/s12144016-9464-9

Valdés-Cuervo, A. A., Sánchez Escobedo, P. A., \& Valadez-Sierra, M. D. (2015). Gender differences in self-concept, locus of control, and goal orientation in Mexican high-achieving students. Gifted and Talented International, 30(1-2), 19-24. doi:10.1080/15332276.2015.1137451

Watters, J. J. (2010). Career decision making among gifted students: The mediation of teachers. Gifted Child Quarterly, 54(3), 222-238. doi:10.1177/0016986210369255 
Woitaszewski, S. A., \& Aalsma, M. C. (2004). The contribution of emotional intelligence to the social and academic success of gifted adolescents as measured by the emotional intelligence scale - adolescent version. Roeper Review, 27(1), 2530. doi:10.1080/02783190409554285 